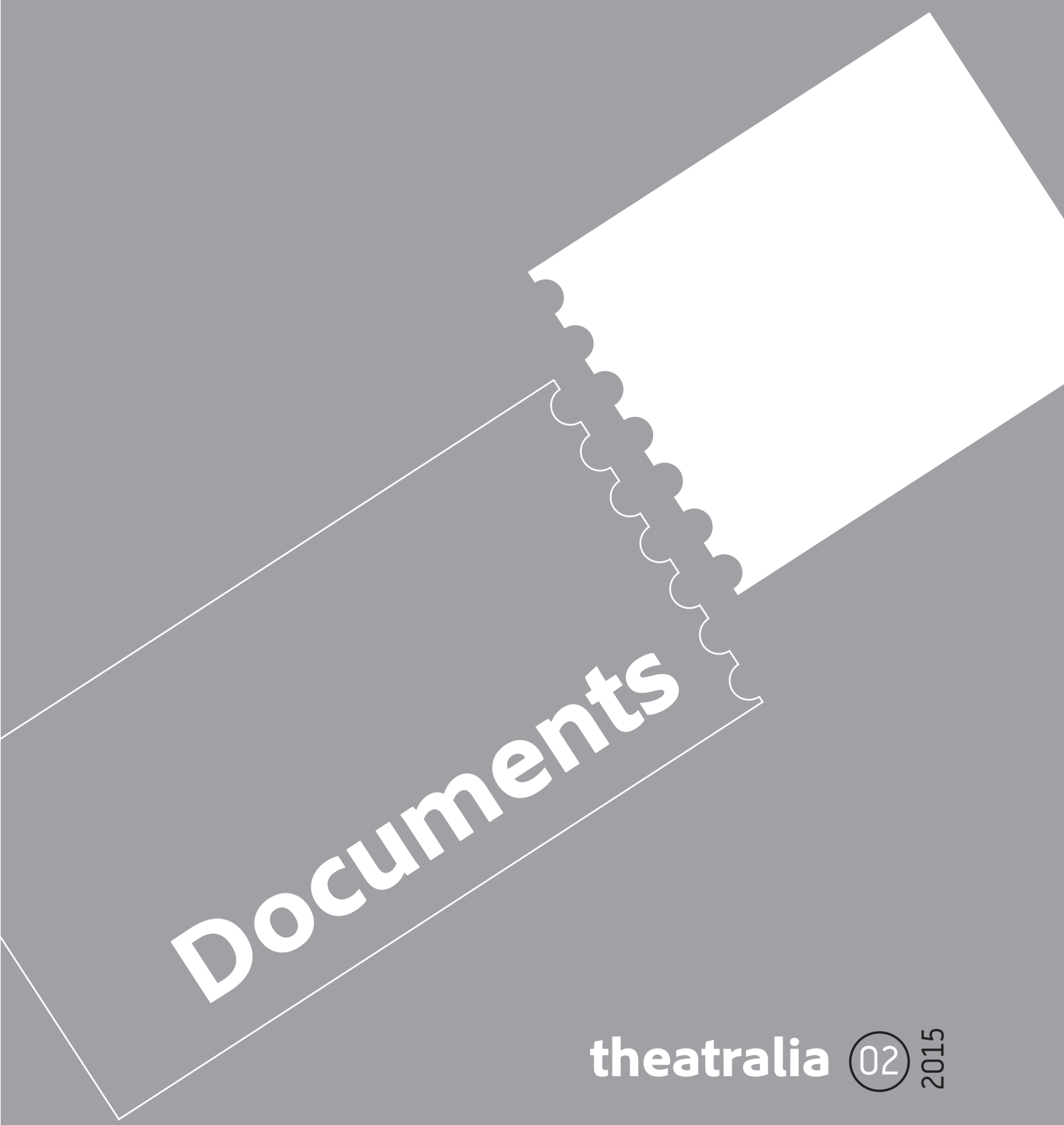



Agnès Novak (Artistic Director, Yorick's Marionette Theatre / Les Marionnettes de Yorick)

with Dušan Petráň (founder Yorick's Marionette Theatre)

\section{Backstage and on Tour with Yorick's Marionettes}

Yorick's Marionettes, also known as Yorick's Productions, operated in the United States of America between 1990 and 2010. Its founder, Dušan Petráň, a native of Brno in the Czech Republic, hand-sculpts all of his marionettes and creates the dramaturgy and scenography for his own productions. He received the title of 'Fellow Master in a Traditional Art Form' from the Rhode Island State Council on the Arts, and has also been the recipient of funding from the United States' National Endowment for the Arts (hereafter NEA) - a Federal Agency that provides for the production of new artistic works and touring, and stands in the place that would, in other national contexts, be occupied by a Ministry of Culture.

Yorick's Marionettes moved to France in 2010 where it now operates under the name Les Marionnettes de Yorick. The company has also created its own cultural association, a status given by the French government after meeting all necessary requirements. This is an equivalent to the Tax-exempt (501c3) cultural organisation delivered by the American government at the condition of meeting similar requirements as those required for the French status. Agnès Novak is the Artistic Director of the company, which she joined in 2001. Besides the creative aspects of writing new material, painting and designing, Agnès assumed responsibility for the company in terms of writing grant applications, accountancy, communication and marketing. 


\section{Czech Marionettes in the United States}

Dušan Petrán arrived in the United States in July 1989. For twenty years, his company operated essentially in New England and toured in different regions of the USA. During that time, the cultural landscape changed shape according to a variety of external factors - many of which had little to do with the world of culture. From the late 1980s up to 2001 there was a particular sense of fluidity, exchanges and communication in what concerned the arts and interest for America's diverse cultural communities; the preservation of these cultural entities formed part of the NEA and other state agencies' missions. That context provided small companies and venues with a fertile ground in which to explore opportunities and open the door for audiences to experience and enjoy a variety of cultural events to which they would otherwise have limited access. A particular window of opportunity opened up for Eastern and Central European culture during the 1990s when, after the fall of the Berlin Wall, a wind of curiosity and openness in relation to countries that had formerly been located behind the 'Iron Curtain' swept across the major cities of the United States.

A professional actor, Dušan Petrán started carving wood whilst a theatre student at the Janáček Academy of Performing Arts (JAMU) in Brno. In Czechoslovakia he had limited access to the tools relevant to the skilled execution of carving, as these were only available to sculptors and sculpture students. In the United States, however, he found that he could buy all the tools he needed and he therefore discovered that he could perfect his art. Soon after his arrival in Boston, Dušan focused his carving skills on the creation of marionettes. This activity was a way for him to keep alive a thread to his Czech roots and he developed that thread from memories of marionette shows he attended during his childhood. Carving from these memories, the actor became the puppeteer, in time creating his own 'troupe' of actors: Yorick's Marionette Theatre - a name inspired by Shakespeare's Yorick. His cast included Smrtka the skeleton, Čert the devil, Vodnik the water sprite, Skřitek the goblin, Čarodějnice the witch and Kašpárek the jester - all characters found in traditional Czech marionette theatres.

Dušan Petráňs work soon attracted the attention of a number of well-established companies. In 1990-1991, the American-Czechoslovak Puppet Theatre in New York commissioned Petráň to carve copies from original marionettes and repair those that had been damaged by time and use. These marionettes had been brought to New York by Czechoslovak immigrants during the nineteenth century and were found at the Jan Hus Church and Neighbourhood House in New York.

Other commissions also came, notably the carving of a life-size figure for the theatre play Beethoven 'N' Pierrot, by Pavel Dobrusky, performed in 1995 at the Denver Center for the Performing Arts, in Colorado. This collaboration was particularly interesting as the production, directed by Dobrusky, a Czech native, was a rare opportunity to bring together a Czech theatre director and a Czech puppeteer/carver in the same 


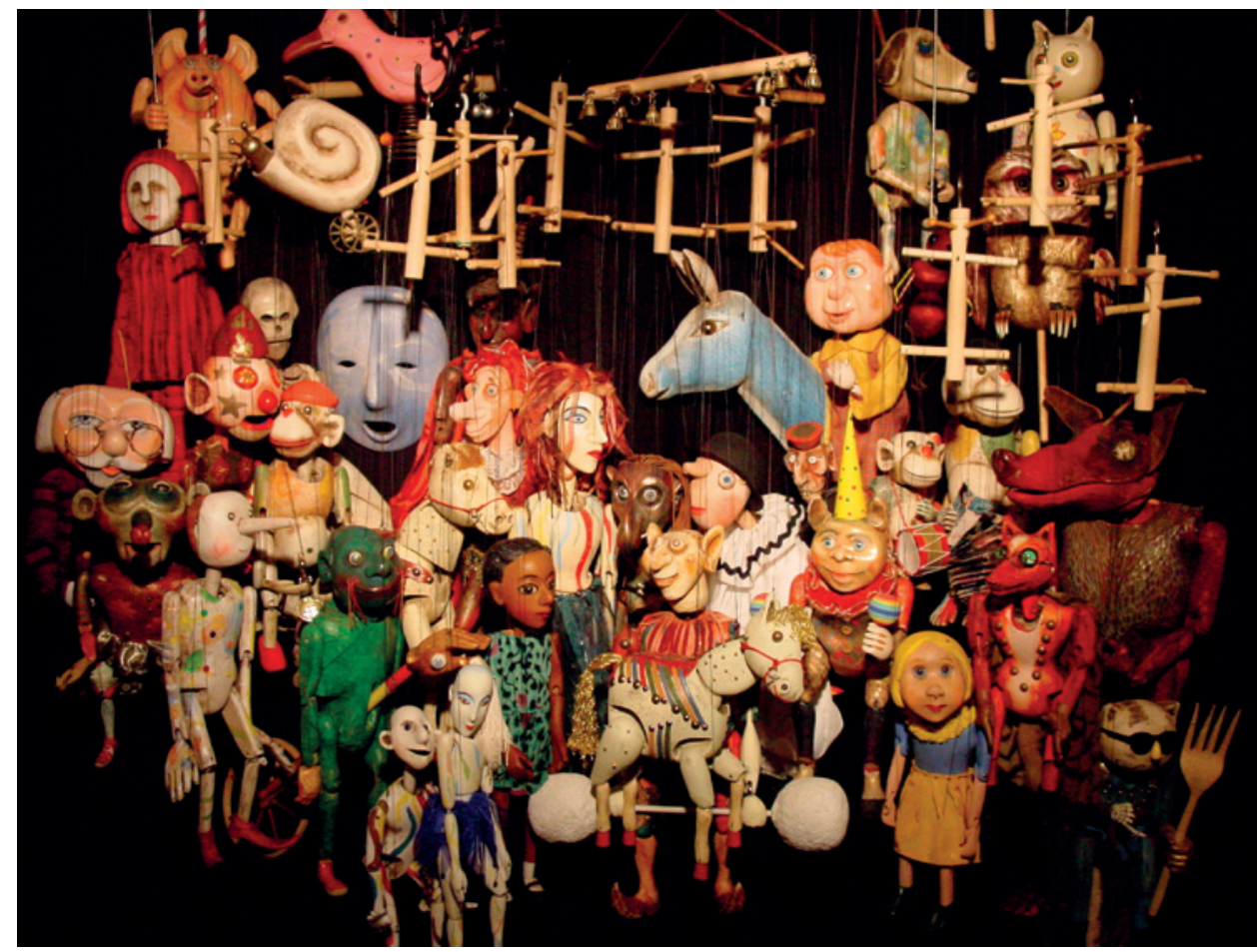

Fig. 1: A world of Marionettes. Photograph (c) the archive of Yorick's Marionette Theatre / Les Marionnettes de Yorick

production. The play received attention and was featured in regional newspapers and magazines.

A theatre residency at Case Western University, Cleveland, Ohio, was facilitated by Pavel Dobrusky in 1998 and Dušan was hired to teach a course on 'Manipulation and Animation of Objects in Space'. Through this practical teaching, students at the University discovered how to bring audience concentration not only onto themselves, but also via and onto objects. This approach was new; hence their receptivity and enthusiasm about the new vistas of experimentation that they found in a theatre of objects. Dušan's emphasis in teaching the course also had historical roots, because combining live actors with objects and marionettes started in Czechoslovakia during the 1960s, the Black Light Theatre being a good example of this trend.

\section{Developing the Company: the Magic of Czech Marionettes}

It didn't take long before Yorick's Marionette Theater performed in schools, libraries, festivals and cultural events in cities and small towns. At these performances, audiences 


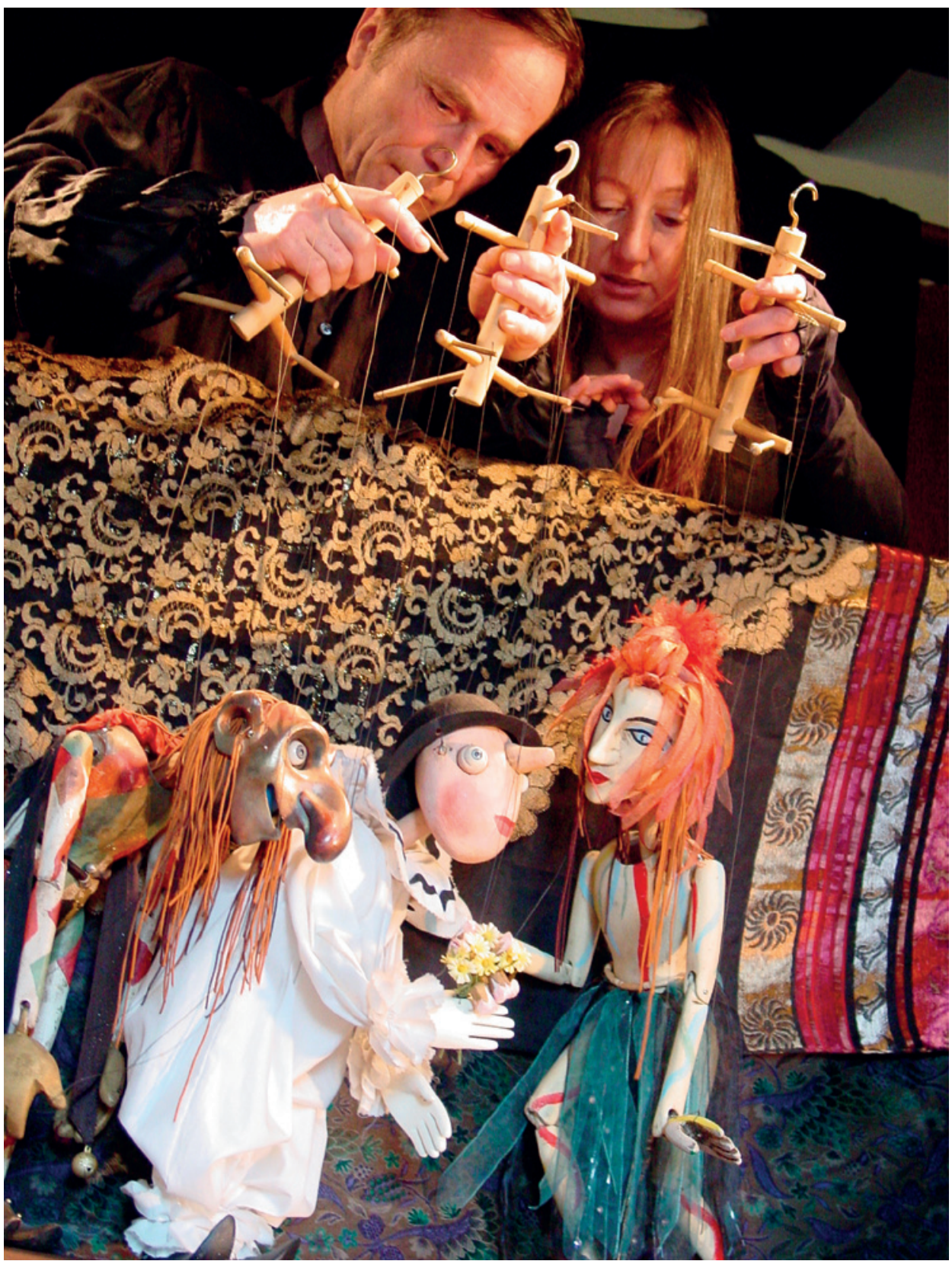

Fig. 2: Dušan Petráň and Agnès Novak in rehearsal. Photograph @ MOUSSA 
were varied and expressed strong curiosity when seeing Czech marionettes, especially for the first time. The marionettes intrigued American spectators, both in relation to their outlook, and their function. Adults were particularly impressed by the skills involved in carving and marionette manipulation. They could recognise the complexity of different artistic fields meeting and merging to produce man-made magic. Among traditional Czech marionettes are two characters, unique to Czech culture, and which attract all eyes and curiosity: The skeleton, whom we named Mr. Bones, and the Devil. Mr. Bones was a great favourite of children, while adults would sometimes get concerned that Mr. Bones, the Devil and the Water Sprite would be too scary for youngsters.

The richness of expression typical of Czech marionettes somehow opens the door to imagination: maybe that is due to the fact that a homogenisation of youth culture has led to so much drowning in the same things these days, so much conformism, so much of Disney and other 'giants' of entertainment. In the end, these so-called 'giants' actually pervert the sensitive minds of children - who grow up to think of Pinocchio, or Sleeping Beauty, as exactly the character that was designed for them by an all-too-prevalent multi-media corporation.

The attractiveness of Czech marionettes in such a context is certainly due to the fact that they are string and rod marionettes, i.e. real objects, and that the characters they portray are from 'another world' - moreover they are strongly connected with the archetypal and with fairy tales. Furthermore, the beautiful carvings of all Czech and Czech-inspired puppets are stamped with a specific Central European look that has traversed the times untouched. It is that quality of a defined visual aesthetic, married with the carrying of so much history that is felt upon meeting the marionettes. There is a mysterious power to them and the contrast with today's world couldn't be deeper: At a time in which small doodles become achievements, it is a humbling affair to meet such superbly crafted figures. They connect us to a deep-seated inner world, a collective unconscious where one can find a space to inhabit and explore. Their Baroque style touches a familiar chord, even when one has never seen a Baroque sculpture in reality, which is the case for many Americans, and for young people particularly.

\section{Examples of Productions}

I joined the company in 2001. As a professional visual artist, I benefited from an apprenticeship programme funded by the state to learn the carving, manipulation and history of Czech marionettes. Soon after I encountered Yorick's Marionettes, Dušan and I started collaborating: I adapted and wrote plays for the theatre, one of which was the Czech story from Josef Čapek's All about Doggie and Pussycat (1996; Povídání o pejskovi a kočičce). The show gave us an opportunity to introduce the origin of the word 'robot' and its creator, Josef's brother, Karel Čapek. 
Most of our productions were created for a public of children aged between three and fourteen years old. One show, entitled The Blind Dates of Colombine, was produced for a public of teenagers and adults. We took inspiration from social themes, in this instance the rise of new internet sites, offering to match people for life. We also asked an American high-school student to talk to us about relationships between boys and girls and we learnt that girls would shun boys who didn't have a car. So we took elements from our immediate environment to create a satirical production. In our work, there is an organic evolution between the environment and culture; another example of this comes in our show Counting Out the Trees. In the back of our house were woods and marshlands, often visited by coyotes. When the land was bought out, the new owner decided to get rid of all the trees, and everyday one could hear the sound of chainsaws. In time, the land became bare. Dušan thought of fairy tales, often set in the midst of forests, and what the consequences of disappearing trees would be for the folk heroes and legends peopling the forests of famous tales. That concept gave birth to a new set of marionettes and a new show in which Pinocchio, Hansel and Gretel, Red Riding Hood and other famous figures were used as the protagonists, looking to punish the man who felled their trees. In the end, Pinocchio quite literally sows the seeds of renewal, by planting the germs of new trees in the ground. The show became very popular with ecologically minded organisations looking for themes that would encourage young minds to preserve nature. Keeping the tradition of Czech marionettes alive whilst also addressing immediate concerns, was as rewarding artistically as it was an intelligent way to remain competitive in the field of live entertainment.

\section{Shakespeare}

One of the most important productions created by the company was Yorick's Marionettes Play Shakespeare in 2007-2008. The project, a long-time dream, was based on a dialogue between Shakespeare and a 'Fool' character, with excerpts from Shakespeare's plays. It was for both of us a complete immersion in the world of Shakespeare, an incredibly enriching experience, and an artist's dream. Dušan carved a set of twenty-five marionettes and animated objects, the first being the Bard himself, followed by others, such as Othello, Iago and Desdemona, Romeo and Juliet, Hamlet and Ophelia, the Witches of Macbeth... The creative process was very profound and the challenges, rather than being felt as obstacles were met with smoothness and excitement. Creating characters of such stature and aura in wood and still keeping a Czech signature on the style was the achievement of a lifetime of work. The result is a magical blend between form and content that particularly befits Shakespearian themes. The book Evoking Shakespeare (1998), by Peter Brook, was an invaluable source of inspiration for our approach concerning dramaturgy. The music used in the production was composed by 


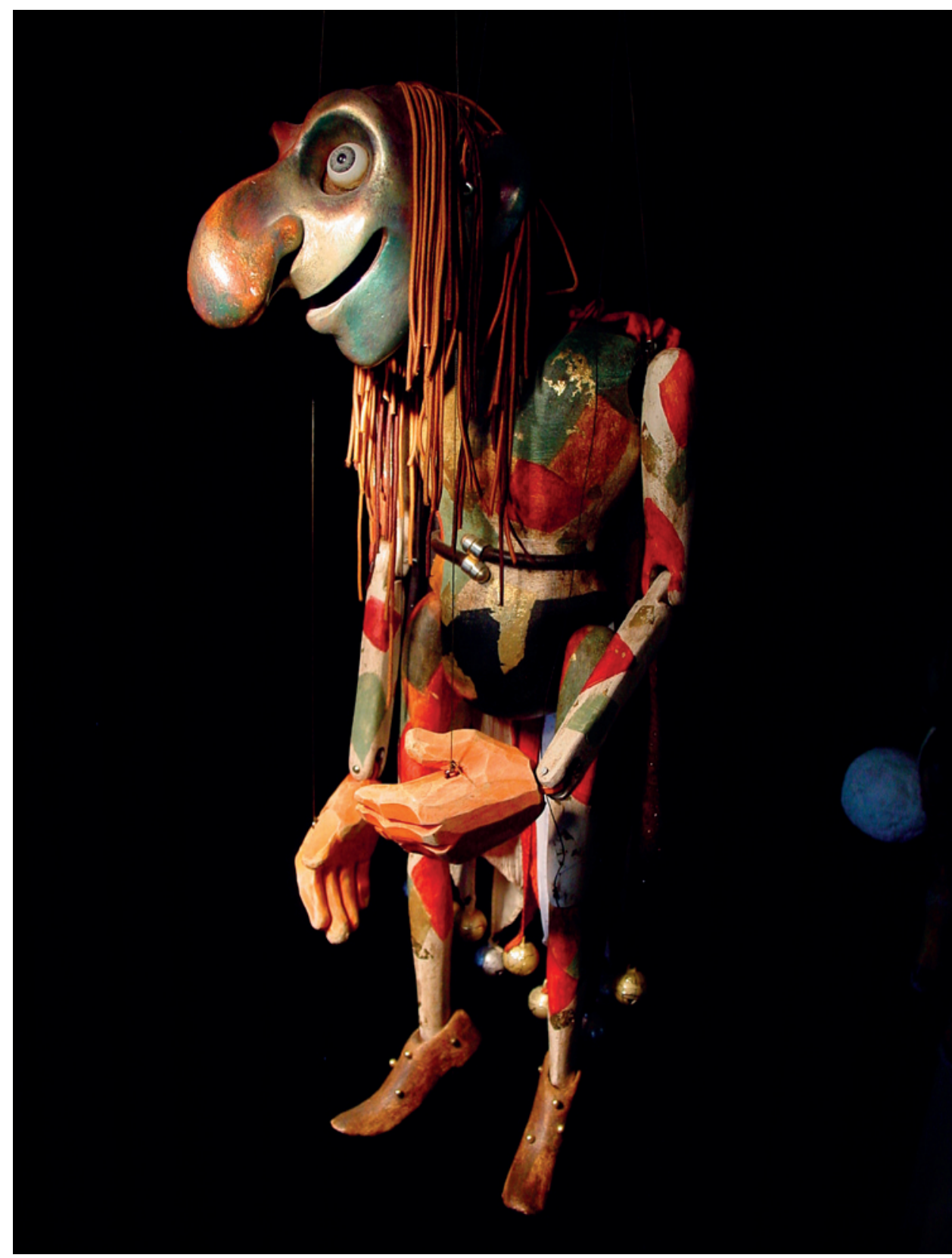

Fig. 3: Harlequin. Photograph (c) the archive of Yorick's Marionette Theatre / Les Marionnettes de Yorick 


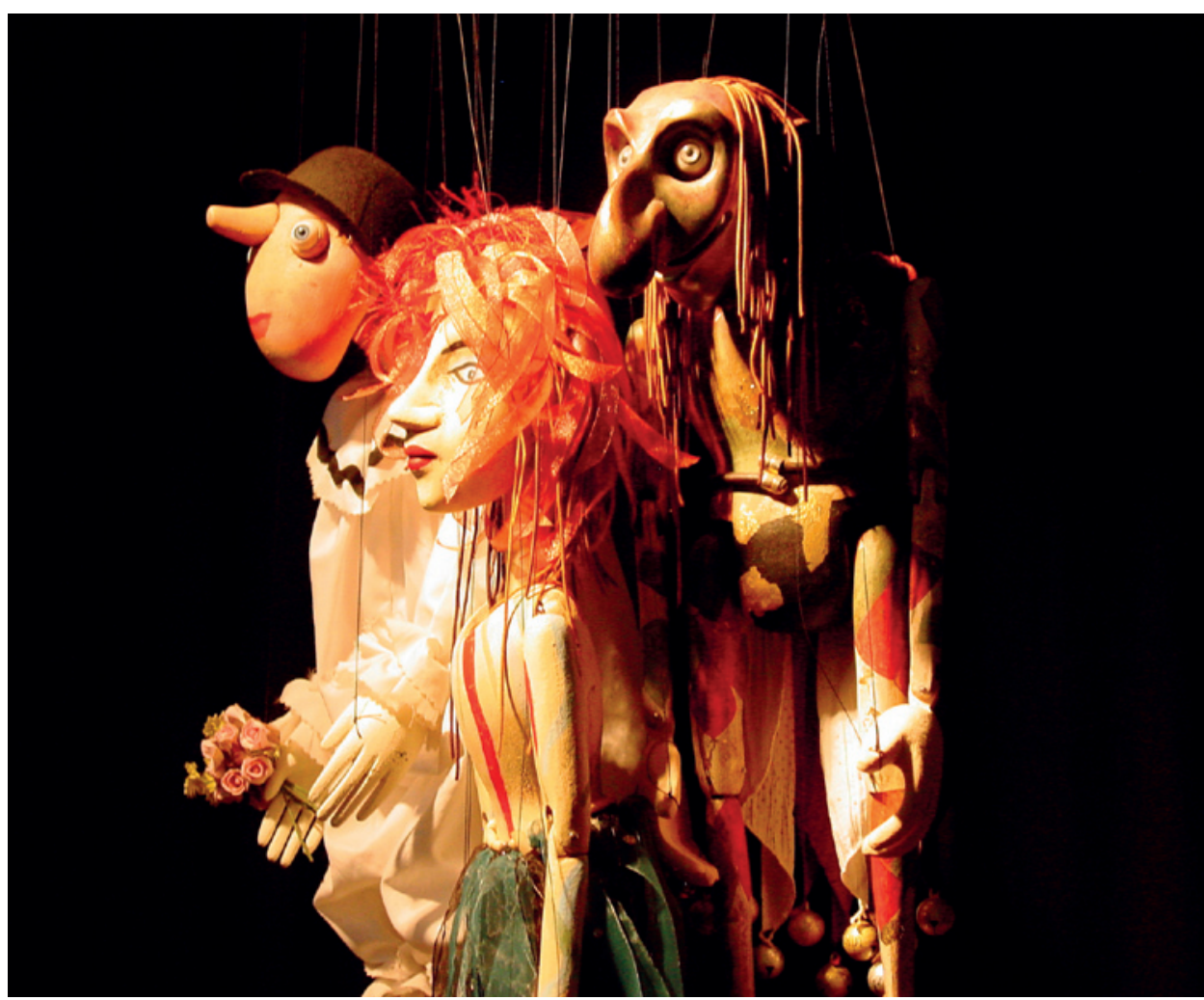

Fig. 4: Pierrot, Colombine and Harlequin. Photograph (c) the archive of Yorick's Marionette Theatre / Les Marionnettes de Yorick

Czech musicians Irena and Vojtěch Havel. The première was held at a theatre in Rhode Island. Amongst the variety of enthusiastic comments we received, one of the most rewarding was that of a young woman, who observed: 'Now, I want to read Shakespeare and understand him more'.

\section{Residencies: Working Closely with Youth}

Residencies were the collaboration of art and social studies teachers, funded by the state or private foundations. For students as well as for us, the experience was always extremely fulfilling: students were immersed in a different world than that of cartoons and screen heroes and the experience was beneficial because the characters encountered were so foreign to American lore. Yorick's Marionettes performed a lot in urban areas and participated in numerous pedagogical programmes, initiating youth to the art of the marionette and the rich panoply of traditional Czech charac- 


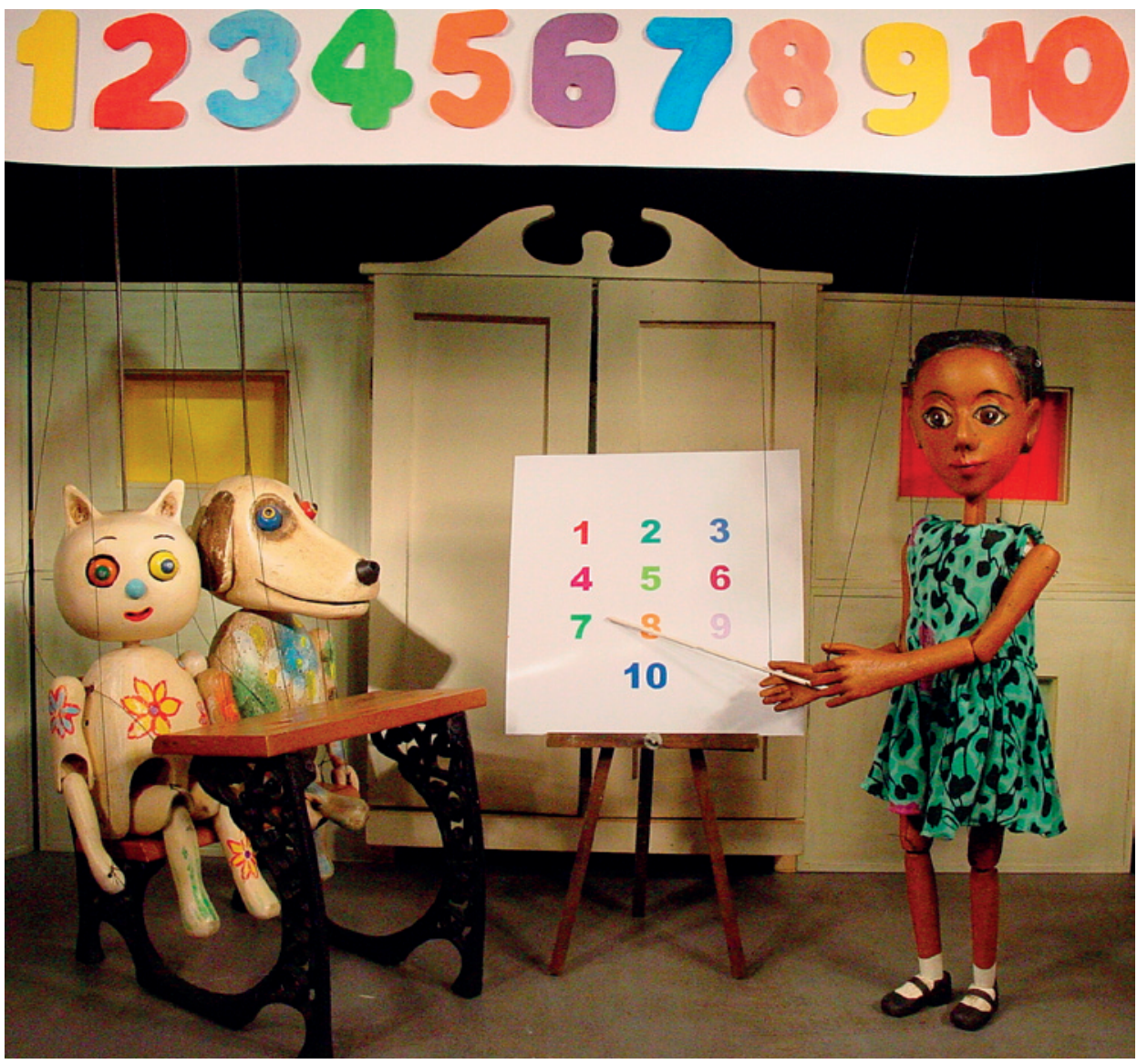

Fig. 5: Cat, Dog and Piccolina. Photograph (c) the archive of Yorick's Marionette Theatre / Les Marionnettes de Yorick

ters. The impact of such programmes went beyond the mission of acquainting youth with a different culture. Marionettes triggered reactions that would deserve a more in-depth study of how individual youths, generally closed to activities falling outside their range of interest, quickly found a medium to express themselves, to challenge and question, to gain self-confidence, and to feel that there is a whole world out there worth exploring.

In short, the marionettes triggered the dormant creativity of young Americans to come out and express themselves, to discover their strengths via their own production of a papier-mâché marionette. In such engagements, the universal need to express a deeper sense of self found a medium that could both give shape to and voice young people's alter egos. The catharsis couldn't be clearer. Culture is an essential part of 


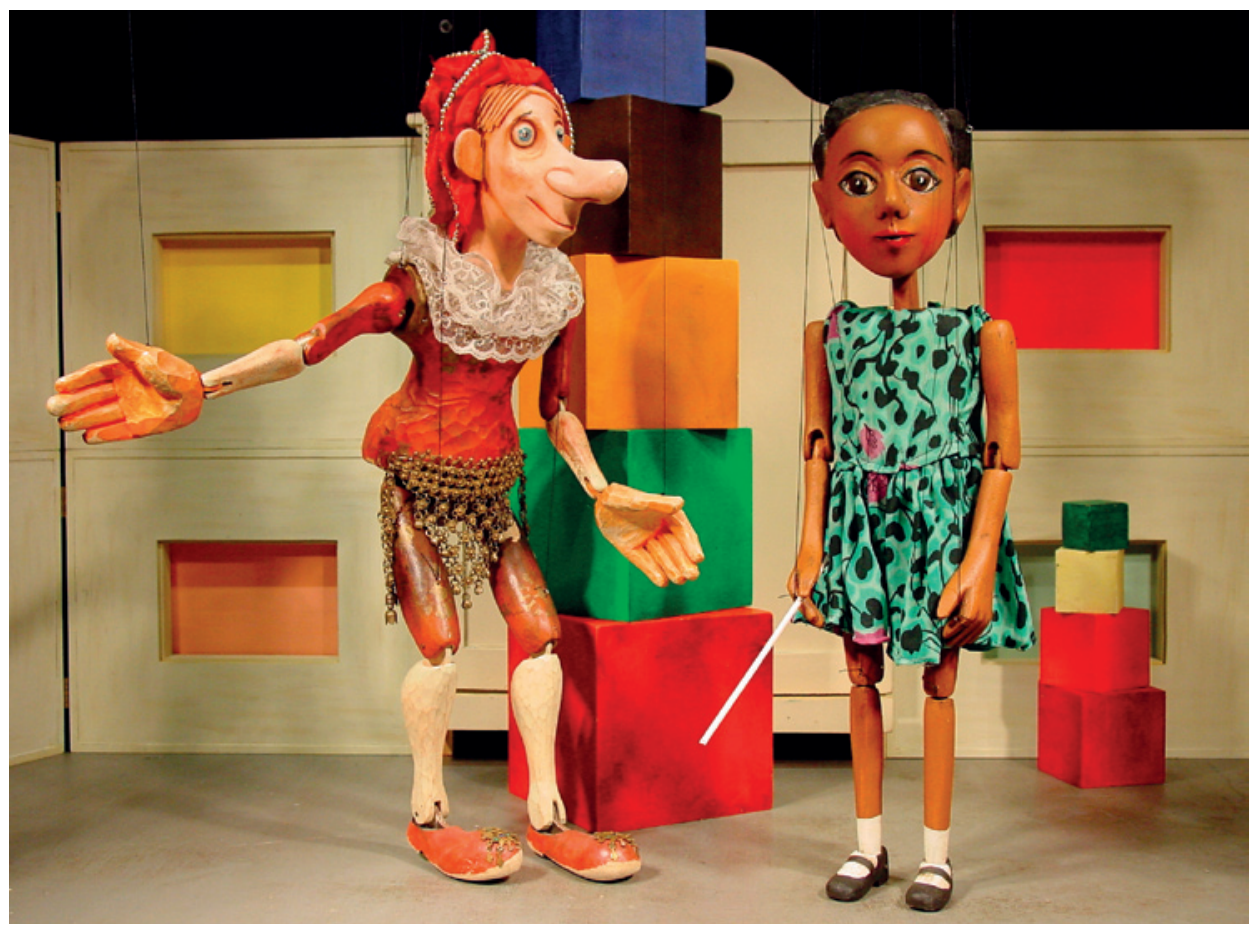

Fig. 6: Jester and Piccolina. Photograph (c) the archive of Yorick's Marionette Theatre / Les Marionnettes de Yorick

education, as well as psychological development. Countless examples describe the depth of such encounters. ${ }^{1}$ In our experience, many teenagers (aged between fourteen and eighteen years) would exhibit aggressive behaviour in their schools and challenge authority, as is the case in most urban public schools. However, once a residency with Yorick's Marionette Theatre started, the behaviour of such challenging individuals changed; their interest kept growing and they gradually became seriously involved. Boys and girls who had been withdrawn opened up and expressed themselves. The notion that marionettes are for little children only, would literally melt at the sight of Dušan performing in front of teenage audiences with the Jester, Mr. Bones and Mr. Pounds (a weightlifter). The humoristic expressions carried by the cast helped to facilitate contact between the teenagers and puppeteers.

1 For examples of academic research into the significance of young people's engagements with culture, narrative, theatre and performance in pedagogical processes, see: NEELANDS, Jonothan. Learning Through Imagined Experience (Teaching English in the National Curriculum). London: Hodder \& Stoughton, 1992; NEELANDS, Jonothan and Tony GOOD. Theatre as a Learning Process, in Peter O'Connor (ed.). Creating Democratic Citizenship Through Drama Education: the writings of Jonothan Neelands. Stoke on Trent: Trentham Books, 2010; BRUNER, J. Narrative and Paradigmatic Modes of Thought, in E. Eisener (ed.). Learning and Teaching the Ways of Knowing. University of Chicago Press 1984; and ROSEN, H. Stories and Meaning. The National Association for the Teaching of English, 1984. 
I believe that such impact is directly connected to the visual aspect of Czech marionettes: their caricatured quality initiated laughs; but the Otherness of the genre and forms inspired wonder and a need to prolong that encounter. The notion of the archetypal would suddenly become a tangible idea worth exploring and playing with. In terms of reaching pedagogical goals set by residency programmes, the programme was a clear success: cultural as well as psychological effects on urban youth went beyond expectations. As a factor in this process, it is important to note that in the context of the United States, one seldom sees Czech marionettes: they are therefore a curiosity that can be used to open up dialogues that go beyond what is assumed or normative in a dominant culture - and it is precisely because audiences were more familiar with the Muppets or Lamb Chop and Howdy Doody that the sight of such unusual characters as our Central European puppets helped our company to create an enriching experience for participants and for ourselves.

Longer residency programmes were developed to permit a more in-depth approach to Czech culture. The format usually included a performance, a presentation of Czech marionettes and their history, followed by hands-on activities such as the study of a Czech fairy tale and the execution of papier-mâché marionettes inspired by the tale in question. The children would subsequently use the marionettes in a production and performance undertaken under Dušan's direction.

In a private school in Providence, Rhode Island, students were asked to read Czech tales in English: Jiří Horák and Jane Carruth's Folk and Fairy Tales from Bohemia (Hamlyn 1973), illustrated by Jiří Trnka and translated by Alice Denešová. They found the stories humorous and enjoyed their rural setting. They learnt of Jiří Trnka and his important place in Czech animation. Apprehending a new culture in this hands on way, via a variety of activities and events, enabled children to deepen and enrich their experience of Czech culture. Many commented on the project as an eye-opener to the complexities of the art of the marionette and felt envious of children who had access to marionette shows throughout their childhood.

\section{Festivals}

Yorick's Marionettes participated in many festivals, which were a great exposure for Czech marionettes. Among the national festivals were two from New England: the Lowell Festival in Massachusetts and the Bangor Festival in Maine. At these regularly scheduled events, traditional artists had an opportunity to show elements of their crafts such as tools and materials during workshops, and later to perform on stage. The festivals therefore condense a great array of animations within a variety of outdoor stages accommodating large audiences.

The Eastern European Festival, held yearly in Massachusetts, was the only such festival in New England. There, one could enjoy Polish, Russian, Bulgarian, Ukrainian 
traditional music and dance, and Czech puppetry, along with Slavic cuisine and traditional costumes. The festival attracted new and older immigrants whose children revelled in the atmosphere. The marionettes were the show all children waited for impatiently. This festival is a good example of the many ethnic festivals that have historically been held in the United States. These were usually the result of a group of individuals concerned with keeping their traditions alive and transmitting them to younger generations since the Slavic populations are quite dispersed throughout the country, except for the Polish community in Brooklyn, New York, and the Central and Eastern European communities in Pittsburgh, Pennsylvania.

\section{Universities and Exhibitions}

The Department of Slavic Studies from Brown University invited us to perform for their event presenting Eastern European cultures. Traditional dances and music and songs were the usual attraction. Dušan's performance was the first time the event had included Czech marionettes. It created a wave of interest from students, professors and the general public that attended the event. At the time, around 2008, there was already a sense that Slavic Studies departments across the North American university landscape were losing students. Cuts were made concerning courses and programmes affecting the quality of such events.

Next, the Animation Department of the Rhode Island School of Design in Providence, a well renowned art and design University, contacted us for a visit at our studio. Students had been introduced to examples of Czech film animation and were familiar with Jiří Trnka and Jan Švankmajer, but they were new to puppetry, especially string marionettes. They were in awe when they encountered all the marionettes hanging in an area specially built for them. Their mechanisms were particularly interesting to students who were keen to learn about the possibilities for their own work. Dušan talked about the context of Czech puppetry and made inferences with the world of animation. The students realised that folk arts are delivered by real people, who do not rely on the crutches of technology, and the result is enchantment and surprise.

An exhibition of puppeteer's tools along with marionettes created by different artists was held at the Rhode Island Foundation in 2003. Dušan's tools were specially highlighted as he was the only performing artist who also carved his own marionettes. Over the years, Dušan's sculptures, which he continued to produce in parallel to his activities as a puppeteer, also became informed by his marionette carving. He had been awarded prizes for his sculptures in exhibits at the Cambridge Arts Association and other venues throughout the 1990s; and from 2003 onwards he was invited to exhibit his marionettes in the context of art shows. 

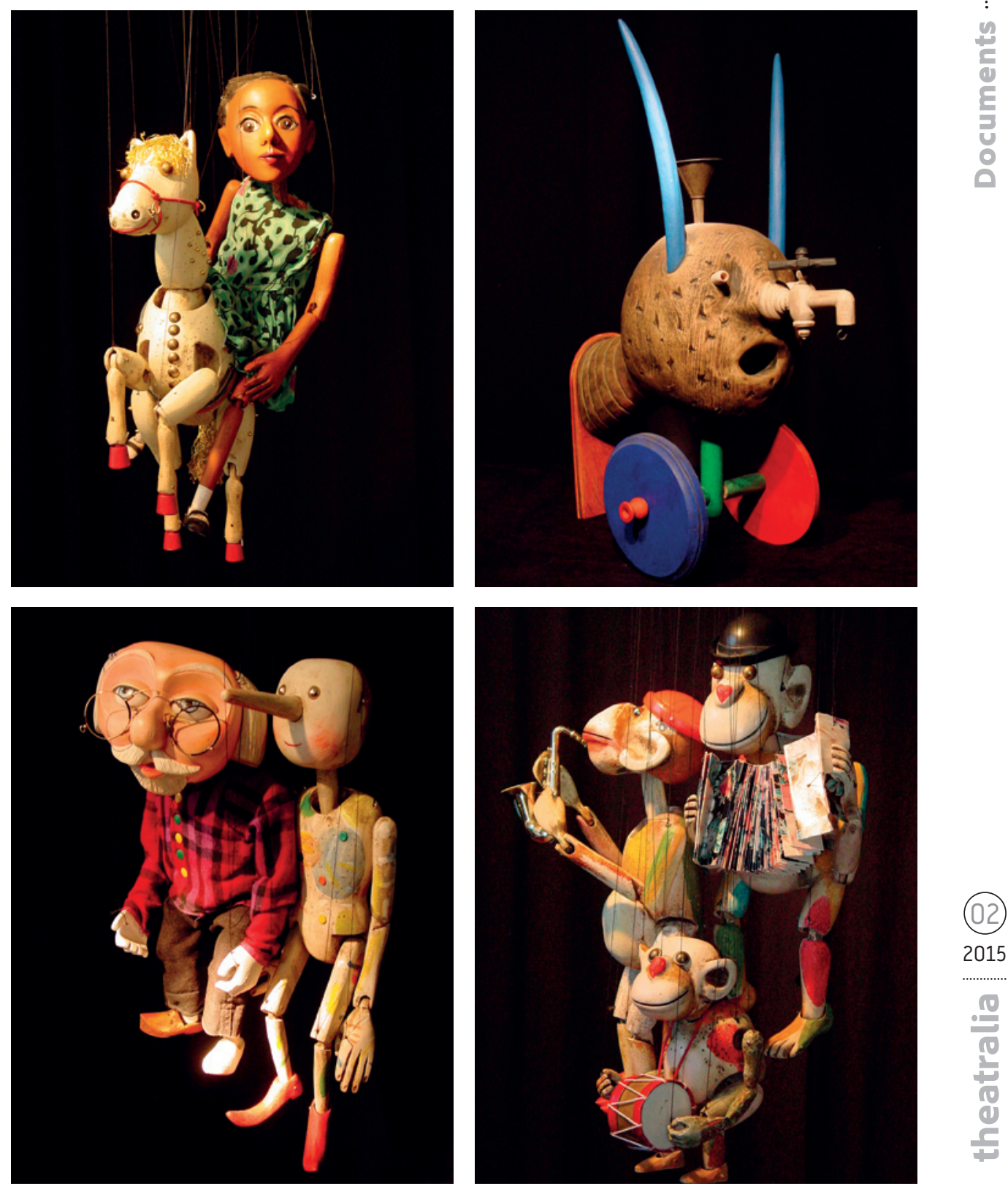

Fig. 7a-d: Piccolina and Pompon (a); Tap Man (b);

Geppetto and Pinocchio (c); Three Monkeys playing musical instruments (d).

Photograph $\odot$ the archive of Yorick's Marionette Theatre / Les Marionnettes de Yorick 


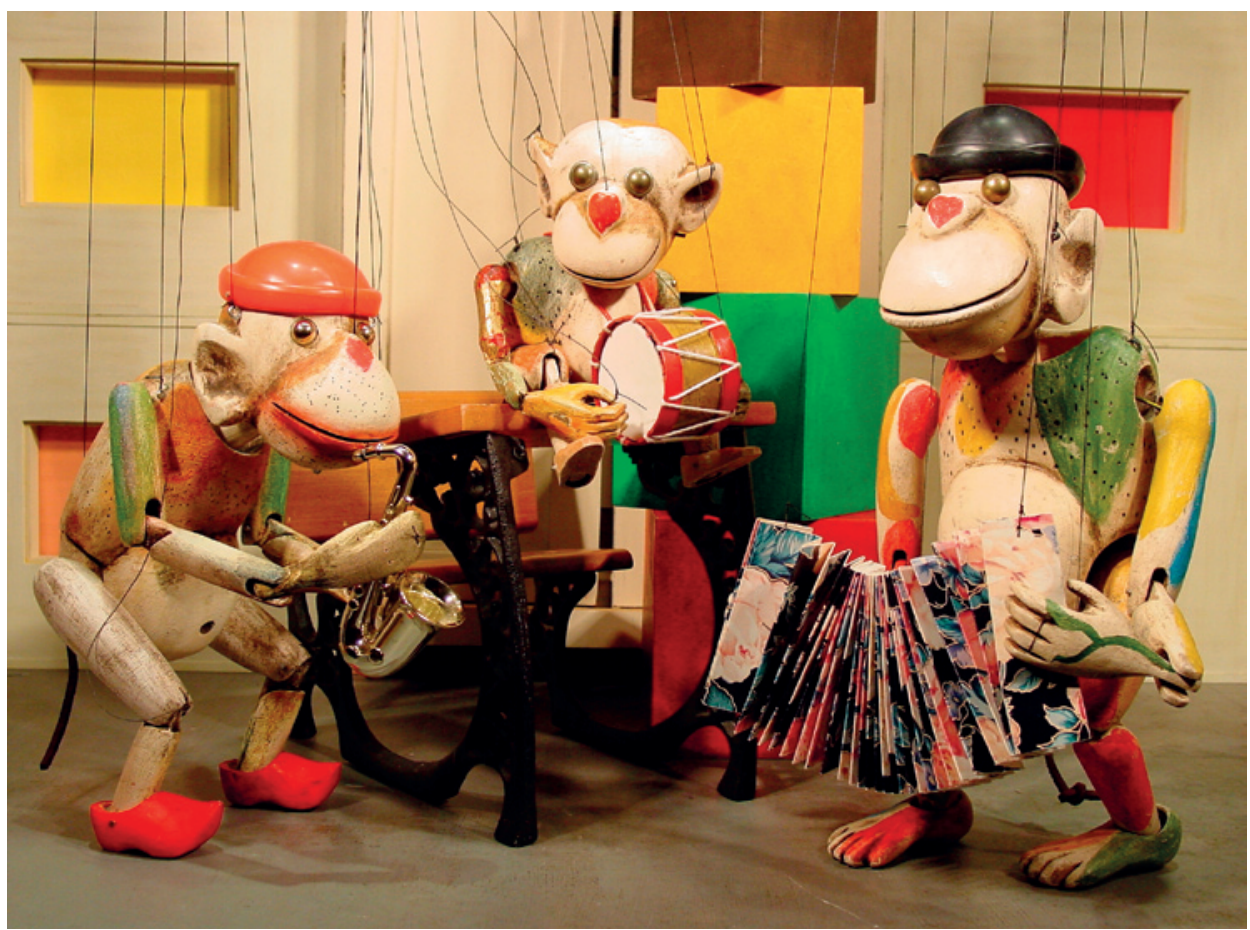

Fig. 8: Three Monkeys playing musical instruments.

Photograph (c) the archive of Yorick's Marionette Theatre / Les Marionnettes de Yorick

\section{Sources of Funding}

After obtaining the status of a tax-exempted cultural organisation, the company could gain access to grants at the national level, which meant that we could apply directly to the NEA. This body awards significant funds as a result of a selection process involving jury panels made up of experts in all artistic fields, as well as well-established artists. The granting process was essentially based on artistic quality and the relevance of the project. We applied for two different grant categories: (i) Excellence in the Arts - which funded regional tours; and (ii) New Works - which funded new productions, including the carving of new marionettes. Yorick's Marionettes obtained grants in both categories, enabling the company to bring in new productions and tours in the whole North-eastern and Central regions of the United States.

The company also benefited from private funding from foundations or endowments for residencies, for new productions and for shows. Among them: the Bank of America Foundation, the Feinstein Foundation, the Rhode Island Foundation and the Britt Nelson Fund. Foundations are particularly eager to support cultural programmes that bring new experiences in schools or after school and so the educational engagement pro- 
gramme of Yorick's Marionette Theatre was particularly relevant and appealing to such funding organisations.

\section{Apprenticeship Programme}

In 2003, Dušan received the Fellowship of Master in a Traditional Art. Along with the prestige coming with the award, the fellowship permitted students with an artistic background or with goals to enter an artistic field, to take on an apprenticeship with Dušan, which would be paid by the NEA. This unique feature of the NEA in a country in which education can be extremely costly deserves to be applauded. Under the regulations of the scheme, the apprentice and master establish specific educational goals for each semester and every year a jury panel would validate the continuation of the apprenticeship based on the validity of work achieved and new goals. The programme lasts three years. During this time, Dušan was able to take on apprentices who were interested in any aspect of carving marionettes, and Czech marionettes in particular. Among his apprentices was a young high school student, Chris Esper, interested in creating his own characters so that he could eventually use them in his animations and films. Chris had heard of our company through an article published in the Providence Journal and contacted us in 2008. Dušan also shared his staging experience with Chris, as well as his skills and talents in dramaturgy and directing. This was about eight years ago. Since the apprenticeship, Chris has gone on to study film and uses his own puppets to fill the roles in his movies; he now works with a larger team on a variety of film projects and to this day, he still sends videos of his new works, asking Dušan for feedback.

\section{Operating a Cultural Organisation in a Changing Environment}

Over our years of operation in the United States of America, we had to wear many hats in order to keep the company growing: our time was divided between artistic activities such as performing, creating new productions, carving new marionettes and writing or adapting new material on one hand, and taking charge of all the administrative chores on the other. We also had to be keenly aware of the cultural environment, as well as the trends affecting audiences. In this regard, changes started to be felt during the decade between 2000 and 2010. The people in charge of hiring artists would ask us not to bring to our shows the characters of Mr. Bones and the Devil for fear that their wooden image would disturb religious feelings. This attitude reflected the overall national mood of the time and, in order fully to explain it, one needs to mention two major 'art scandals' from the late 1980s that had shaken public opinion to the point that censorship in artistic expression became a hot debate 
at national and political levels. The question of funding with taxpayers' money art that was deemed to be 'blasphemous' was perceived as deviant. The most notorious affairs were the Robert Mapplethorpe exhibit at the Corcoran Museum of Art in Washington, D.C. in $1989,{ }^{2}$ and Andres Serrano's 'Piss Christ' ${ }^{3}$ - a photograph winner of the Southeastern Center for Contemporary Arts 'Awards in the Visual Arts', in 1987. The conservative segment of politicians and population were appalled at the fact that both institutions received funds from the National Endowment for the Arts. During and after this period, one could feel that productions needed to fulfil patrons and audiences' need for 'light' subject matter, something non-controversial, entertaining and geared more towards happy endings. The after-effect of these two affairs for our theatre was most strongly felt after 2001, when a wave of conservatism in every field (inspired in large part also by the attacks on the World Trade Center) struck indifferently at small and large companies. The cost was self-censorship and Yorick's Marionette Theatre put Mr. Bones and the Devil to rest.

In tandem with this narrowing of interest and openness to things deemed un-American came a computer games revolution, which meant that a new generation of young audiences emerged who were more interested in the power of screens than the power of the stage. The advance of special effects in movies and in live performances, together with a wider fascination with the new gadgets (tablets, smartphones etc.) coming into people's lives eventually competed too strongly with what was perceived in our theatre as being an old-fashioned world. In the new environment, Dušan thought of incorporating 'special effects'. After a few attempts, however, he gave up the idea and thought that keeping the simplicity and innocence of the medium was more effective.

As we kept touring and performing, we began to sense a significant difference in the quality of the audience and their ultimate goal of being entertained. We therefore realised that to propose productions with deeper significances was not a wise choice - because only a segment of audiences would enjoy more profound and artistically challenging content. One had carefully to weigh the balance between entertainment and art.

2 In 1989 a posthumous exhibition entitled Robert Mapplethorpe: The Perfect Moment was slated to be exhibited at the Corcoran Museum of Art in Washington, D.C. The exhibition contained photographs depicting sadomasochistic and homosexual sexual practices, as well as images of children that were considered to be indecent. Several members of the gallery's executive, of the US Senate and of conservative and religious organisations, such as the American Family Association, used the exhibition to initiate a debate about the legitimacy of the NEA - with the express intention of having its funding either entirely cut, or significantly reduced.

3 The full title of the photograph is Immersion (Piss Christ). The 1987 work is a $150 \mathrm{~cm}$ x $100 \mathrm{~cm}$ glossy, colour-saturated Cibachrome print that depicts a small plastic crucifix submerged in what appears to be a yellow liquid. Andres Serrano has claimed that the liquid is his own urine in a glass. The photograph was one of a series that Serrano made with subject matter of classical statuettes submerged in fluids, including milk, blood, and urine. Because Serrano received NEA funding for the work, there was a controversy about statefunded blasphemy, on the one hand, and arguments that the funding of such a work ruptured the divide that is understood to exist in American society between the church and the state on the other. 


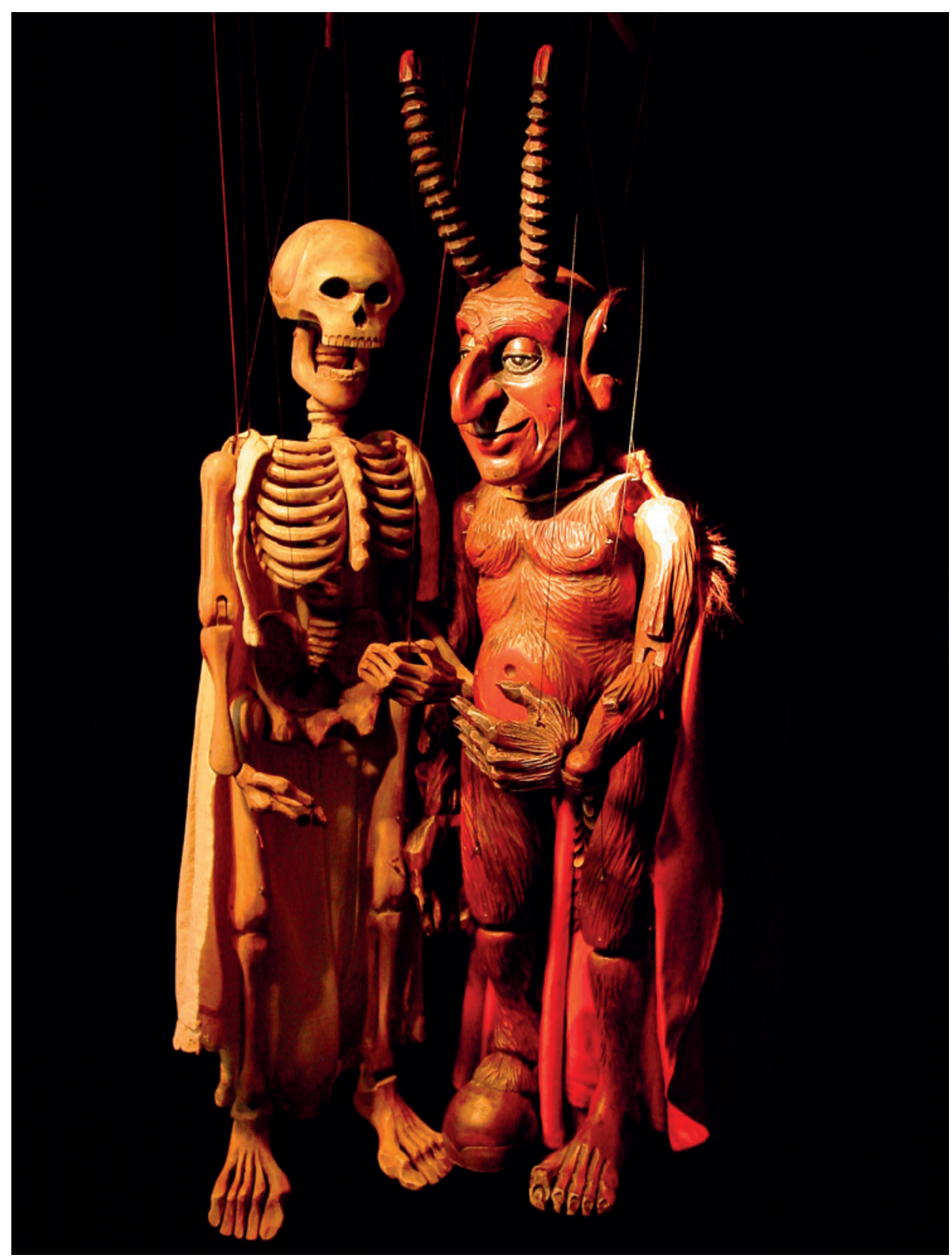

Fig. 9: Skeleton and Devil. Photograph (c) the archive of Yorick's Marionette Theatre / Les Marionnettes de Yorick 


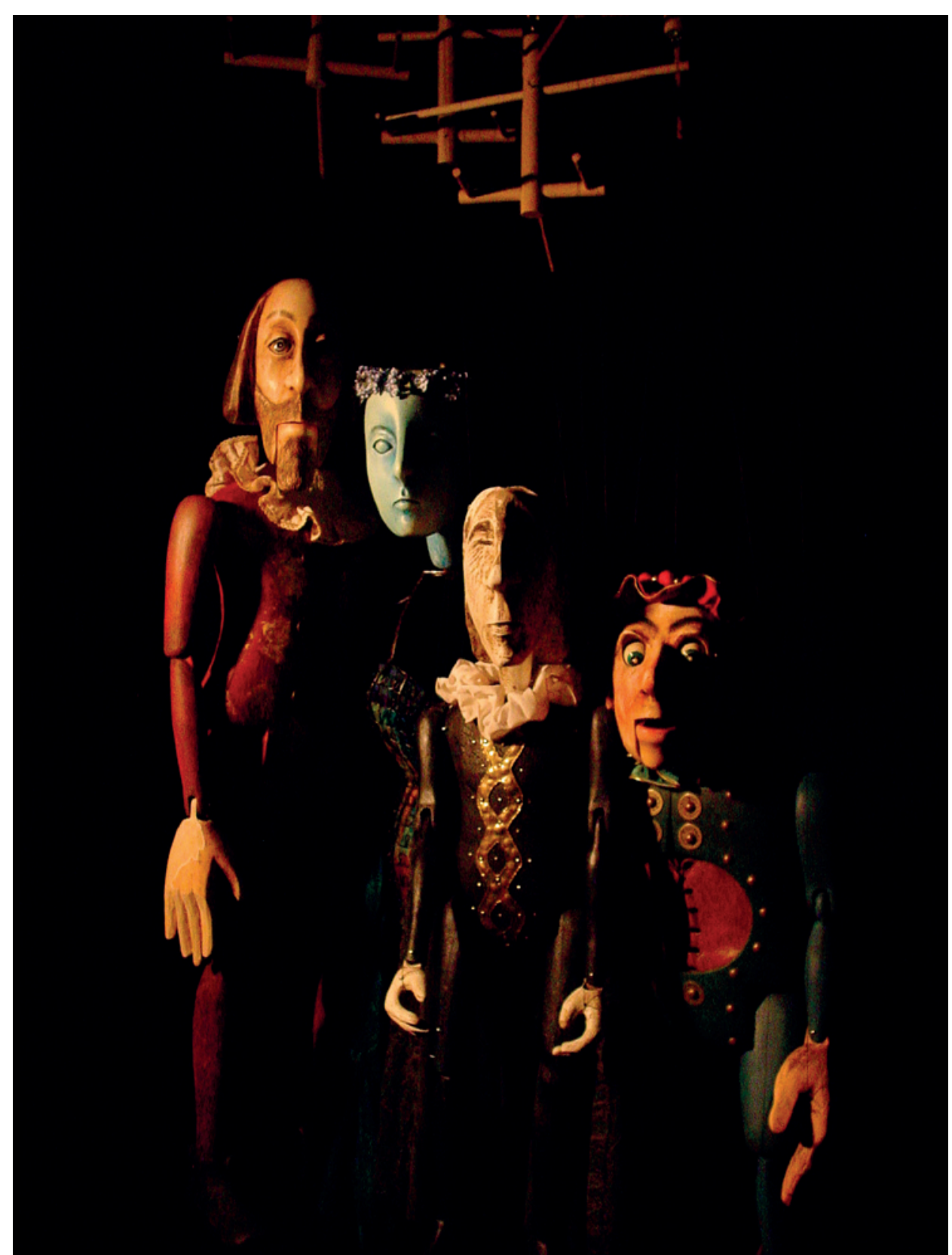

Fig. 10: Shakespeare, Ophelia, Hamlet and the Fool. Photograph @ the archive of Yorick's Marionette Theatre / Les Marionnettes de Yorick 

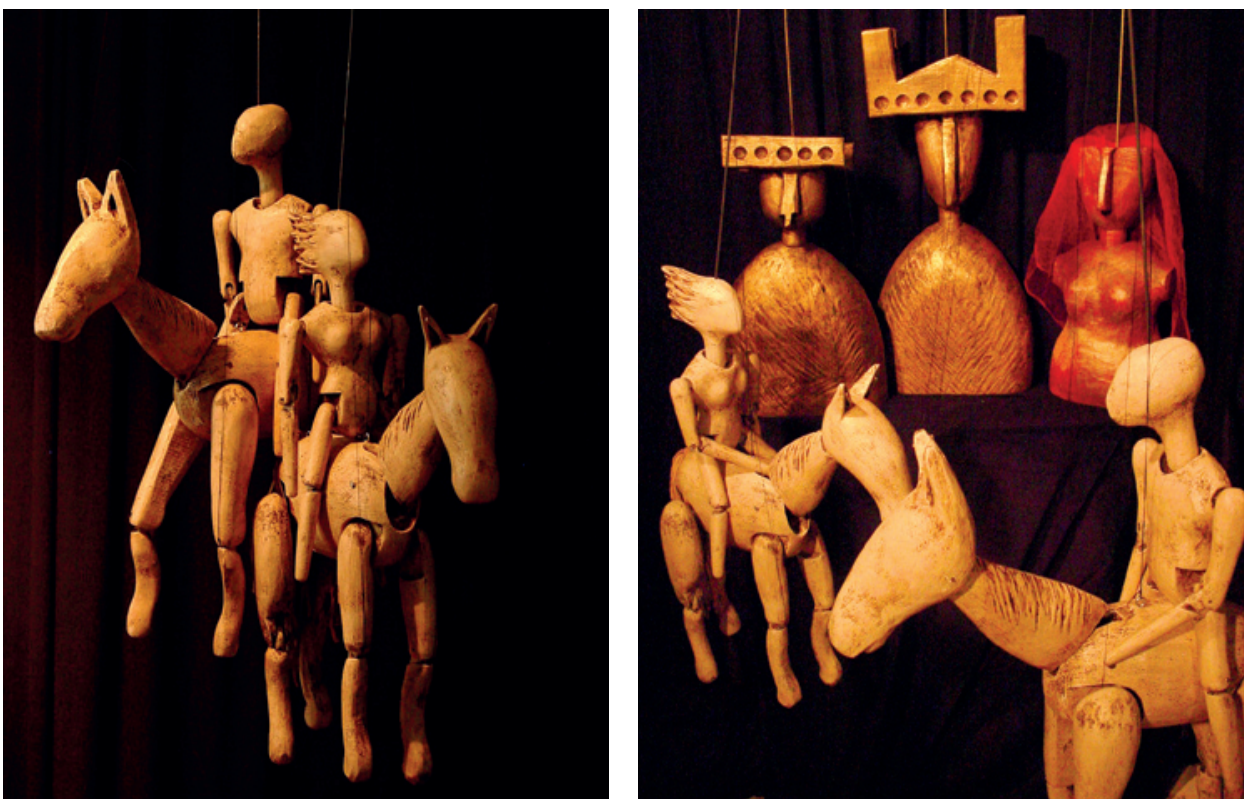

Fig. 11a+b: Romeo and Juliet (a), with Macbeth in the background (b). Photograph @ the archive of Yorick's Marionette Theatre / Les Marionnettes de Yorick

\section{Beyond Time and Cultures}

A beautiful story sprung at the beginning of my involvement with Yorick's Marionettes. Upon learning of my encounter with Dušan, a very close friend who is African-American asked me if Dušan could repair an old marionette whose strings had become wildly entangled. An elderly Jewish woman who had herself received the marionette as a present had given my friend the marionette, an African-American little girl, when she was ten years old. My friend named the marionette Sweet Pea. She also made this statement: 'I would like for Dušan to use Sweet Pea when he can, during shows or residencies so that little black children can see a marionette they can identify with. Keep her for ten years; and after ten years, give her back to me'.

Dušan repaired the strings, built a new control for the marionette and we did some research about the origins of Sweet Pea. The result was that we discovered that she was created in the early 1930s, at which time a lot of newly composed materials were used to create parts of figurines and objects called 'Americana'. We used Sweet Pea in all of our residency programmes, and created a role for her in each of our productions. Of course she became an important marionette in our cast, because children of all colours wanted to get close to Sweet Pea: They had never seen anything like it. The marionette intrigued children as well as teenagers; she inspired them and facilitated their puppet creations. She also eased first contact with teenagers in our residencies. 


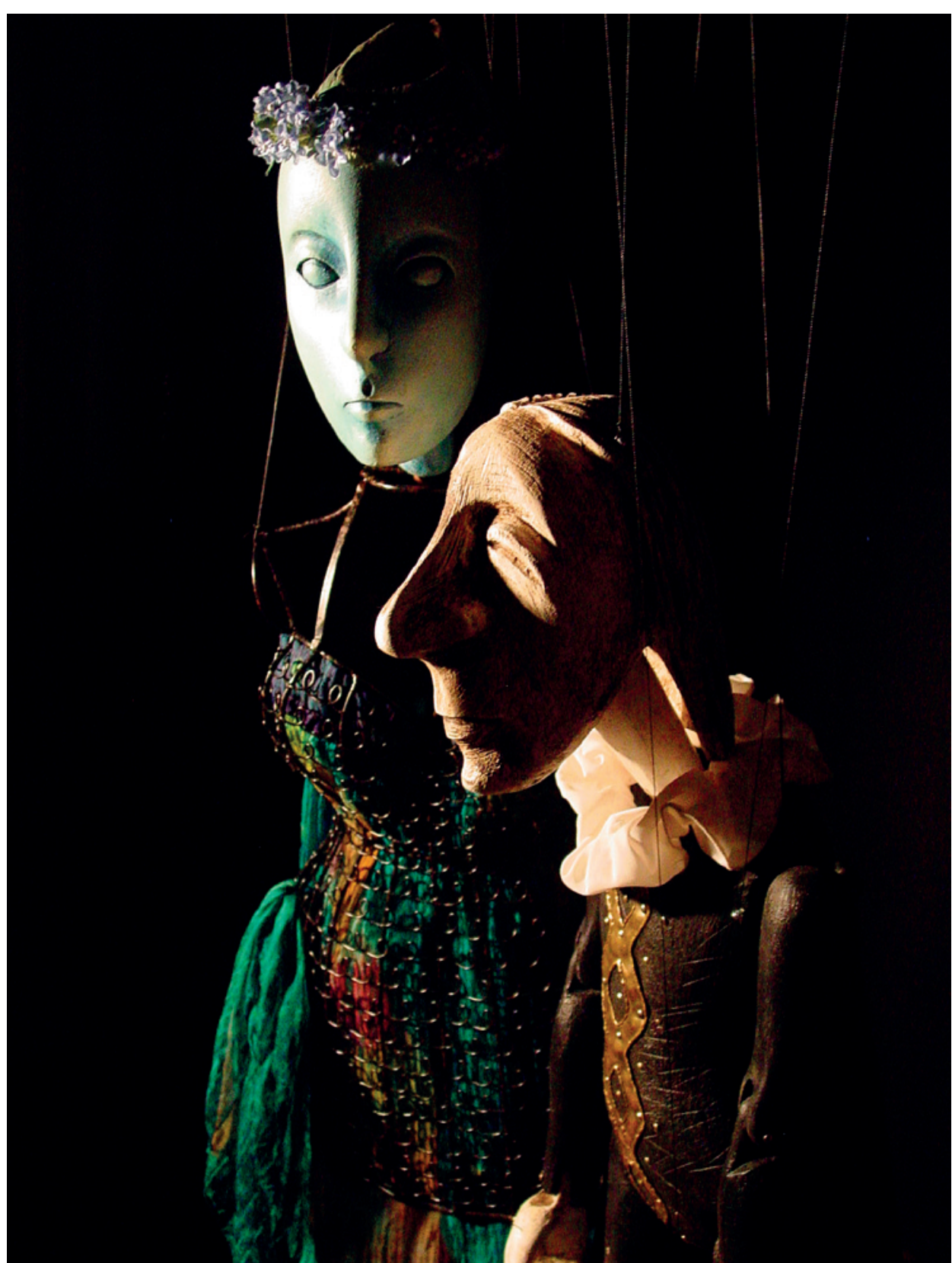

Fig. 12: Ophelia and Hamlet. Photograph @ of Yorick's Marionette Theatre / Les Marionnettes de Yorick 
A few years before giving back Sweet Pea to her owner, Dušan decided to make a little sister inspired from Sweet Pea: We named her Piccolina.

\section{The Media}

Many articles were written in local and regional newspapers about the company's shows and Czech marionettes; from a long list, these included pieces in The Boston Herald, The Boston Globe, The Providence Journal, The Arts North Journal, and the Denver Center for Performing Arts. When the company was hired yearly from 1995 until 2009 at the Boston First Night event, Dušan was selected amongst other performers for a television interview aired on Boston's TV5 channel. Images of Dušan's marionettes were also published in professional articles and books, such as Czechoslovak-American Puppetry (HOŘEJŠ 1994); Puppets, Masks and Performing Objects (BELL 2001); Contemporary Doll Collector (2007, issue 1); Loutkář magazine (ERML 2011).

Other changes occurred after the events of 9/11: budgets were drastically decreased and the consequences were sharp cuts in residencies at the local level. Audiences also decreased, as people in general were less willing to attend public events outdoors. Just as things were slowly beginning to get back to normal, the financial crisis of 2008 hit, and generated an even deeper crisis in the arts. In reality, it has proven to be much more damaging than the previous one: well-reputed theatres have closed down in all of the major cities, including New York, something never seen before. At the time of the financial crisis, we had been working on our Shakespeare production and had received funds to create the production and then tour it. We performed for cultural associations and schools, but the drastic cuts in funds prevented a full-blown tour. Had it been another time period, we would have been able to tour as in previous years.

Very soon after being elected President, Barack Obama created an emergency fund to save cultural entities. Unemployment for a large segment of the population working in the arts was being felt throughout artistic fields: dance, theatre, music, or fine arts and special funds were allocated to local State-level arts councils, who would in turn decide which companies would receive financial support. Decisions favoured larger theatres that had become State institutions and had more personnel at their charge. The result was devastating for smaller companies. After thirty years of a successful career, one of our puppeteer friends decided to retire early because his company was unable to face the new context. Our theatre was able to function at a reduced level thanks to on-going bookings for yearly performances within a large and diversified network of partnerships.

In 2010 however, for family reasons, we moved to France (from which country I originate). In twenty years of work in the United States, our company had developed a solid career and been able to expand its potential. In France we had to start anew, recreating all of our productions in French, as well as establishing a new network. 


\section{The French Cultural Environment}

A little note here about the origin of the word marionnette (which comes from the French Marion, a nickname for Mary). Historically, this term also designated little figurines of the Virgin Mary. Starting from the seventeenth century, however, the word was used to designate any type of figurine, in wood, religious or not, and dolls sometimes used in sorcery.

Dušan performed at the Festival d'Avignon in 2004 and the audience had been very positive and stunned by the marionettes' uniqueness. Aesthetically, they fit very well with the French people's love for the unusual. Positive feedback ensured that our company could generate enough interest to continue developing. In a French context, the cultural institutions that exist in relation to funding and development are similar to those of the USA; but the closed circle of festivals was not as easy to penetrate. However, within a year, the number of artists' residencies with which we were engaged and the frequency of our shows increased throughout the southern and central regions. Word of mouth was the most efficient publicity because a sense of wonder and respect for the craft is felt everywhere that we perform.

In particular, we have responded to a demand for productions addressing a very young public: children in nurseries and thus infants from birth to three years of age. The widespread need to bring marionettes to very young children is absent in the USA. In France, however, parents are eager to expose their children from very early on to storytellers, musicians and puppeteers. Encouraged by the little ones' excited reception, they don't hesitate to repeat the experience yearly. For this constituency, we have developed two new productions, one of which being a re-adaptation of the Josef Čapek story All about Doggie and Pussycat (Povídání o pejskovi a kočičce) in French; we have also had the opportunity to perform both English and French versions for an immersive English language programme.

As is the case everywhere, economics dictate the cultural climate; and the crisis affecting countries in Europe is being felt right now (2014/15) in France. Small organisations, such as the language programme mentioned above closed for lack of funding, schools have higher priority items to deal with than puppet shows, and cities are getting hit by the same austerity-driven cuts. In 2013, a municipal councillor in a small town of the Aude department told us that cultural funds were drastically decreased for 2014 and that for 2015 there were no funds at all. Whether our company was stamped as a Czech Marionette Theatre or not wouldn't make a jot of difference, because all artists are affected whatever their field of work. So it is not a lack of interest that is the problem in remaining active as a Czech marionette theatre, but rather the overall state of the economy that dictates cuts and gives priority to other needs. 


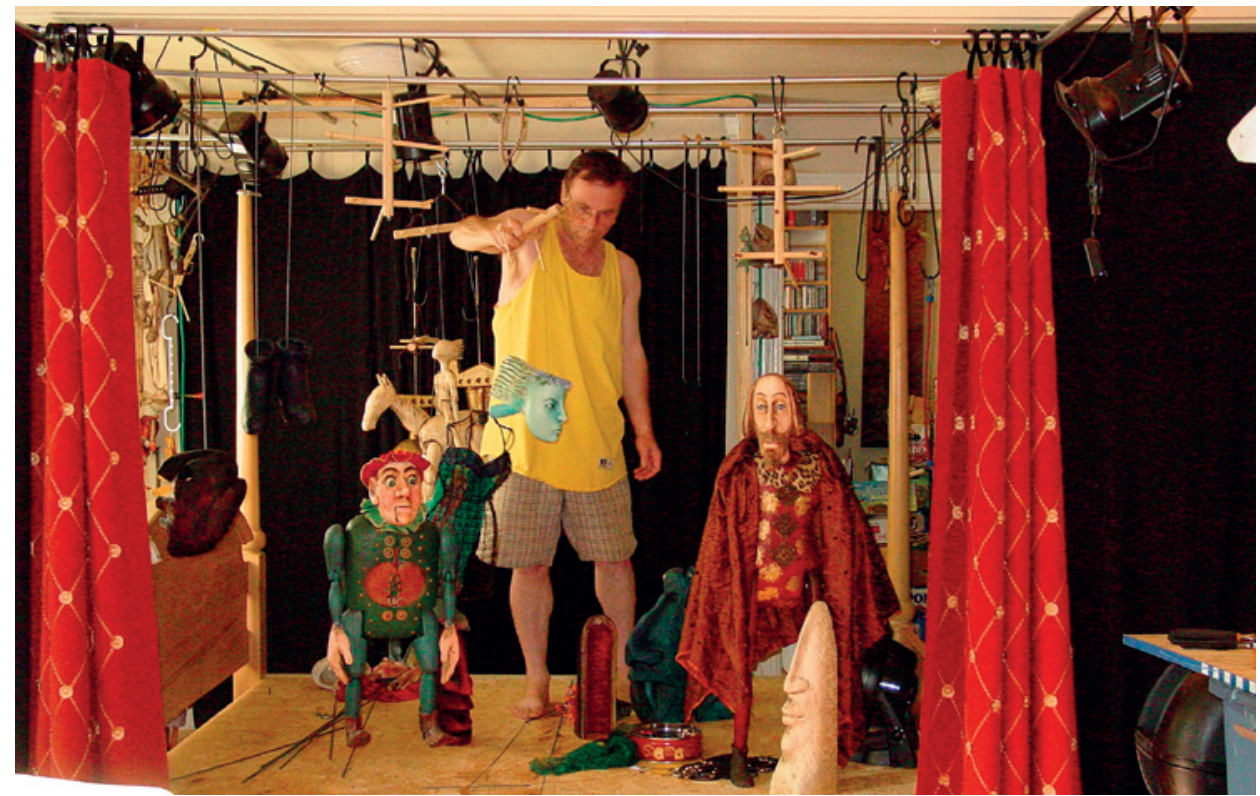

Fig. 13: Dušan Petráň working on Shakespeare. Photograph (c) Agnès Novak.

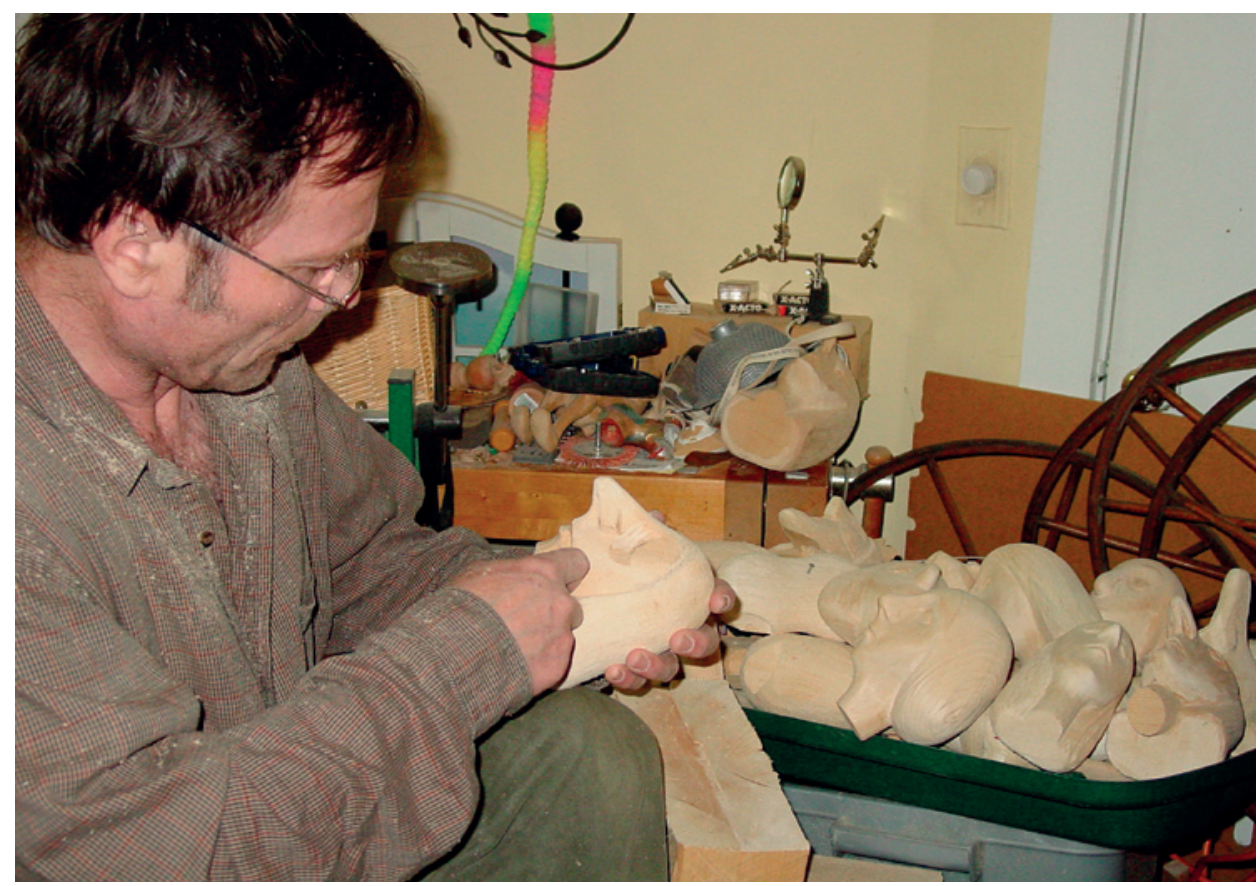

Fig. 14: Dušan Petráň in his workshop. Photograph @ Agnès Novak. 


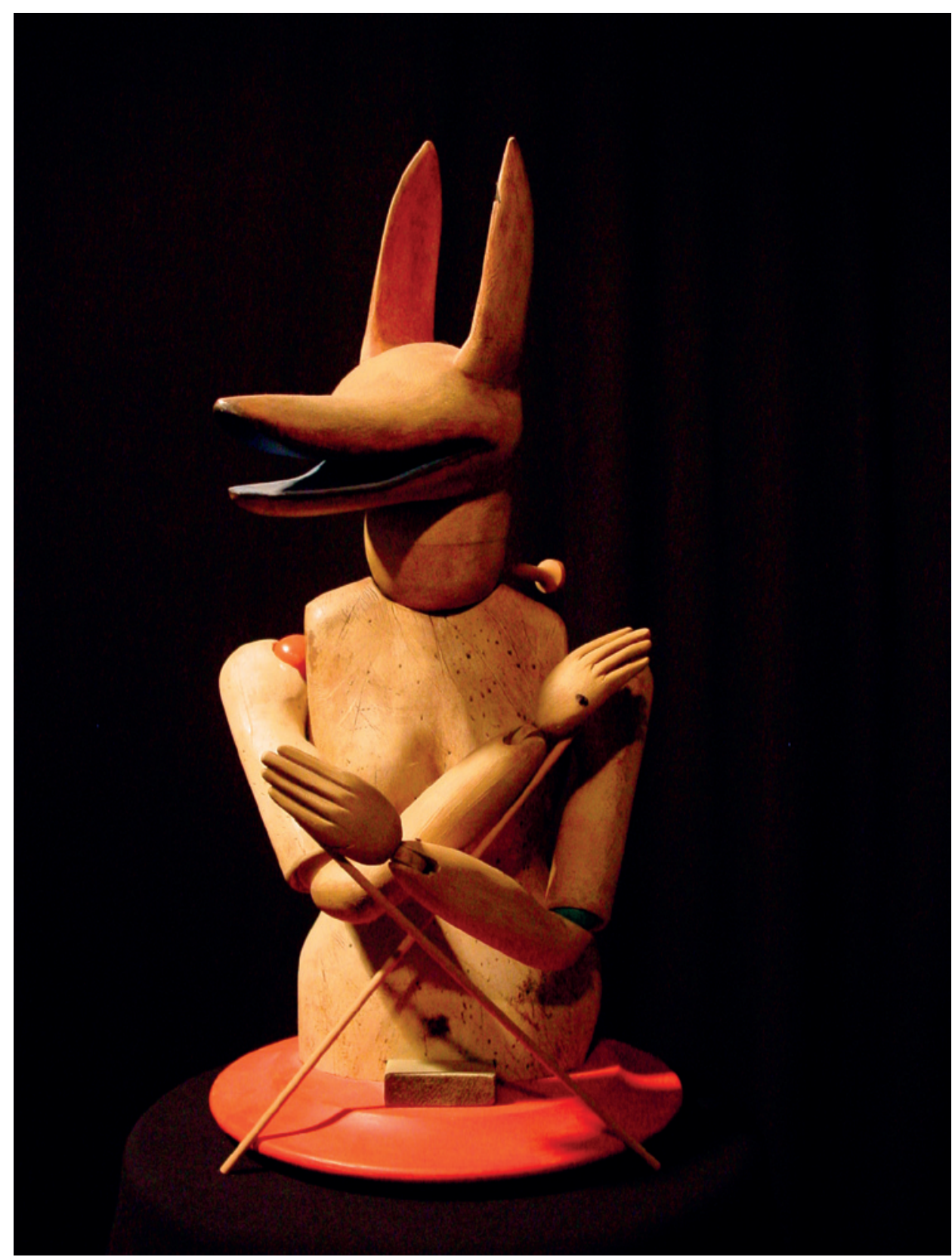

Fig. 15: Vixen. Photograph (c) the archive of Yorick's Marionette Theatre / Les Marionnettes de Yorick. 


\section{Globalisation and Culture}

An important question arises in light of the issues that I have outlined in North American and European contexts above. It is the following: How can small theatre companies survive, stamped as cultural entities in a globalised world?

In a globalised world, the culture of dominant trans-national and international powers tends to overshadow indigenous, ethnic cultures. In order for small ethnic groups to keep their traditions thriving and the artists that represent them able to do their work, national networks are vital. The first and most important element for a given culture is therefore to be able to be part of the global world through promotion by the nation of origin and via foundations and other entities whose mission is to preserve the traditional arts of that people, region or nation.

Without help from institutions and access to funds, a small company cannot survive the on-going crises generated by external conditions. Culture cannot depend upon a political economy, otherwise the danger is that a dominant hegemonic culture will emerge, and, of course, the more powerful a nation, the more it has the means to become dominant. There is a need at a high level to put into place an organisation whose mission is to promote, protect and support European traditional arts - and it is in a global context that a vision of unique and independent artistic traditions has to be developed and implemented.

I believe we can learn a lot from the United States' model of the National Endowment for the Arts: the agency functions democratically: juries are composed of experts, administrative responsibilities are realistic, and artists are not asked to be literary or mathematical geniuses in order to write a grant and establish a budget. That is not so in France: If the writing of a grant is more and less the same in both countries, in France the demand for administrative papers is such that the amount of work to write a grant doesn't warrant the amount of the grant itself which is limited to about 1,500 Euros. This is much less than is granted by cultural agencies in the USA. Each nation needs to assess how best to promote their culture outside their borders by creating necessary institutions vested with a clear mission and using those already in place. For these structures to work efficiently, they need to be headed by people invested in the idea of promoting their culture, capable of raising funds, as well as creating partnerships and collaborations.

\section{Czech Cultural Centres}

In New York and Paris, embassies have attached to their missions Czech Cultural Centres whose remit is to bring Czech culture to the public eye via exhibits, concerts and conferences. Our company has contacted both; but nothing came out of it in either case. There seems to be a flow of Czech artists able to exhibit and lecture via the centres, in keeping with the Cultural Centres' mission. These may not have yet developed networks 


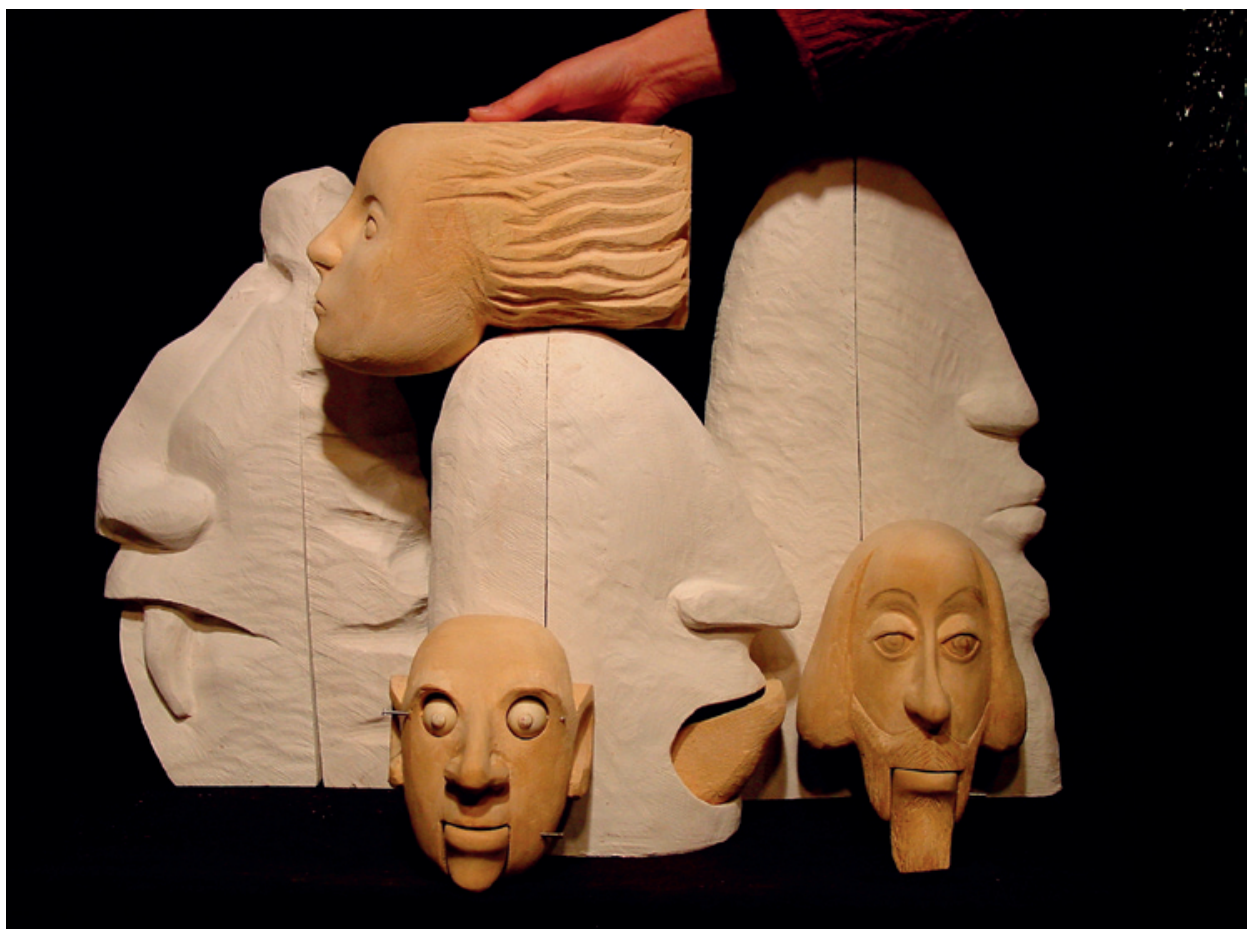

Fig. 16: A sculptural work in progress. Photograph (c) the archive of Yorick's Marionette Theatre / Les Marionnettes de Yorick.

and the stable funding that is needed to grow, as well as the necessary staff in order to bring into the picture Czech artists living abroad as well. Cultural centres are an important asset for traditional arts and for the communities they represent. They are a bridge with the 'old country' for those who live outside its borders and for connecting artists on both sides of its frontiers. It does take time, money and experience to meet specific goals, which is why experience in raising funds via events and networking is fundamental.

A manifestation such as the Eastern European Festival held in Massachusetts could happen in Europe; however cultural institutions in the USA are vested with a mission to protect traditional arts; and funds are easily gathered via state and private entities to support this imperative. In contrast, there is a void in Europe concerning traditional performing arts. We cannot stress enough the importance of finding financial support for traditional arts; they are as valuable as archaeological sites. 


\section{Conclusion}

Responses to Czech marionettes in both the United States of America and France demonstrate that the medium defies place, age and time; it touches all generations beyond their level of sophistication not only when visiting the Czech Republic but also outside its borders. The performances of Yorick's Marionette Theatre / Les Marionnettes de Yorick have fascinated very young children and equally brought smiles to pensioners' faces; they've made people dream and laugh in each place that we have been privileged to go. Despite their inanimate nature when out of human hands, in performance marionettes are live matter, they transmit and transform, they make us feel deeper feelings, question fundamental issues of good and evil, they trigger our imagination, fill our voids with poetic images, they participate in our being better human beings in an age of sophisticated gadgets that often render us less sensitive to our surroundings.

Such a rich world is a treasure worth all possible efforts to keep it alive and share.

\section{Bibliography}

BELL, John. 2001. Puppets, Masks and Performing Objects. Cambridge, Mass.: MIT Press, 2001.

BROOK, Peter. 1998. Evoking Shakespeare. New York: Theater Communications, 1998.

ERML, Richard. 2011. Z pohádky do pohádky [From Fairy Tale to Fairy Tale]. Loutkáŕ [The Puppeteer] 61: 1 (January 2011): 28-31.

HORÁK, Jiř́ and Jane CARRUTH. 1973. Folk and Fairy Tales from Bohemia. Transl. by Alice Denešová; illustrated by Jiř́ Trnka. Hamlyn Publishing Group, 1973.

HOŘEJŠ, Vít (ed.). 1994. Czechoslovak-American Puppetry. New York: GOH Productions/ Seven Loaves, 1994.

NOVAK, Agnès. 2007. A Poetic Encounter. Contemporary Doll Collector 17: 1 (January 2007). Norton Shores: Scott Publications, 2007: 38-41. 
Agnès Novak (with Dušan Petráň)

Backstage and on Tour with Yorick's Marionettes

\section{Summary}

This article documents the story of Yorick's Marionettes, a company established by a Czech performer and puppet maker Dušan Petrán in 1990. The company was active in the USA between 1990 and 2010, and has been resident in France since 2010, developing the cultural heritage of traditional Czech puppets.

\section{Keywords}

Dušan Petráň, Agnès Novak, Yorick’s Marionettes, Yorick’s Productions, Czech puppet theatre, USA independent theatre, USA arts funding, cultural change

DOI: $10.5817 /$ TY2015-2-11

Agnès Novak (yorickmarionnettes@hotmail.com) is the Artistic Director of Yorick's Marionettes Theatre Company that operated in the USA between 1990 and 2010 and in France since 2010. 